\title{
Anaesthesia and Insulin Secretion: the Effects of Diethyl Ether, Halothane, Pentobarbitone Sodium and Ketamine Hydrochloride on Intravenous Glucose Tolerance and Insulin Secretion in the Rat*
}

\author{
A. Aynsley-Green ${ }^{1}$, J.F. Biebuyck ${ }^{2}$, and K.G.M.M. Alberti ${ }^{3}$ \\ Nuffield Department of Clinical Medicine and Metabolic Research Laboratory, Nuffield Department of Clinical Medicine, \\ The Radeliffe Infirmary, Oxford, England. \\ Received: September 26, 1972, received in revised form: April 9, 1973, accepted: April 13, 1973
}

\begin{abstract}
Summany. Fasting hyperglycaemia occurred in $48 \mathrm{~h}$ starved rats after $30 \mathrm{~min}$ of anaesthesia with ether or halothane. Plasma insulin increased only with ether. Halothane caused basal hyperglycaemia in fed rats, but decreased plasma insulin by $50 \%$. Intravenous pentobarbitone $(30 \mathrm{mg} / \mathrm{kg})$ did not affect blood glucose in starved rats, but decreased plasma insulin with a small rise in blood glucose in fed rats. Following intravenous glucose $(0.5 \mathrm{~g} / \mathrm{kg})$, hyperglycaemia and impaired glucose tolerance with normal insulin/glucose ratios occurred in starved animals anaesthetised with ether and pentobarbitone. The latter had no effect on glucose tolerance in fed rats. In contrast, halothane caused hyperglycaemia without glu-
\end{abstract}

cose intolerance in starved animals, but decreased the insulin response by $40 \%$ in fed animals. Ketamine $(30 \mathrm{mg} /$ $\mathrm{kg}$ ) caused only a $15 \%$ increase in glucose area in starved rats and was otherwise without effect. Halothane had no significant effect on glucose stimulated insulin secretion. in the isolated perfused rat pancreas. - Possible mechanisms for these effects are discussed.

Key words: Anaesthesia, glueose intolerance, plasma immunoreactive insulin, blood glucose, perfused rat pancreas, ether, halothane, pentobarbitone sodium, ketamine hydrochloride.
The effects of anaesthetic agents on carbohydrate metabolism in man and experimental animals have been widely studied since the original observation by Reynoso [1] that glycosuria occurred during ether anaesthesia. Interpretation of human data is often complicated by the use of associated drugs for premedication, induction and maintenance of anaesthesia during surgical procedures [2]. In the rat recent work has shown that several anaesthetic agents profoundly affect hepatic carbohydrate metabolism in vitro [3] and have a pronounced influence on blood metabolites and insulin in vivo, the effects varying with dietary state [4]. However, few reports have been concerned with a direct comparison of the metabolic effects of different anaesthetic agents under carefully controlled experimental and dietary conditions, following an exogenous glucose load.

We report below the results of such a comparative study of the effects of ether, halothane, pentobarbitone sodium, and ketamine hydrochloride, on glucose tolerance and plasma insulin in starved and fed rats.

* Presented in part at the Meeting of the Medical and Scientific Section of the British Diabetic Association, York, England 14-15 April, 1972.

1 Wellcome Junior Research Fellow.

2 Nuffield Research Fellow; Present address: Dept. of Anaesthesia, Harvard Medical School and Massachusotts General Hospital, Boston, Mass. 02114, U.S.A.

3 Research Officer.

\section{Material and Methods}

Special Chemicals

Diethyl ether (Anaesthetic Ether B.P.) was obtained, from MacFarlan Srnith Ltd., Wheatfield Road, Edinburgh; halothane "Fluothane", 2-bromo-2-chloro-I,I,I. trifluoroethane) from Imperial Chemical Industries Ltd., Pharmacouticals Division, Alderley Park, Macclesfield, Cheshire, England; sodium pentobarbitone (Nembutal) was obtained as a pure powder from Abbott Laboratories Ltd., Queensborough, Kent, Fngland, and ketamine hydrochloride ("Ketalar", 2-(O-chloro-phenyl)-2-(methylamine) cyclohexanone hydrochloride) was supplied as a powder by Parke-Davis Laboratories, Hounslow, Middlesex, England. Hexokinase and glucose-6-phosphatase were obtained from Boehringer Corp. (London) Ltd., London W5.

\section{Anaesthetic Vaporizers}

The Abingdon Vaporizer (Longworth Scientific Inst. Ltd., Abingdon, Berks. England) was used for diethyl ether, and the Fluotec Mk. III (Cyprane Ltd., Keighley, Yorkshire, England) for halothane.

\section{Analytical Methods}

Immunoreactive insulin was assayed by a micromodification of the double antibody method of Soeldner and Slone [5] on plasma derived from blood treated with ethylenediaminetetra-acetic acid (EDTA) as described previously [6]. Blood glucose was measured by a hexokinase method [7] using a neutralised perchloric acid extract of whole blood.

$$
\text { Animals }
$$

Male albino Wistar rats (Scientific Products Farm, Ash, Kent) weighing $250-300 \mathrm{gm}$ were used throughout. Free access to water was allowed at all times. Fed rats were allowed access to food, whilst starved rats had food 
withdrawn $48 \mathrm{~h}$ before the intravenous glucose tolerance test.

Femoral vein and artery cannulae were inserted under light ether anaesthesia $16-20 \mathrm{~h}$ before testing, and kept patent with $0.1-0.2 \mathrm{ml}$ saline containing $100 \mathrm{U} / \mathrm{ml}$ heparin as previously described [8], the rats being placed in restraining cages until the experiment. Food consumption dropped slightly during the period of restraint $(12 \pm 4 \mathrm{~g}$ compared with $20 \pm 4 \mathrm{~g}$ for unrestrained animals).

\section{Experimental Design}

Inhalation anaesthesia was commenced immediately after an initial arterial blood sample $(0.3 \mathrm{ml})$ had been taken $(-30 \mathrm{~min})$. Two further samples were taken at $15 \mathrm{~min}$ intervals and then glucose $(0.5 \mathrm{~g} / \mathrm{kg})$ injected intravenously in $15 \mathrm{sec}$ as a $50 \%(\mathrm{w} / \mathrm{v})$ solution. Further arterial samples were taken at 1,2.5, 5, 10, 20 and $30 \mathrm{~min}$ after the end of the glucose injection, anaesthesia being maintained throughout.

For intravenous anaesthesia, samples were taken 30 min and 5 min before glucose $(-30$ and -5 min) with the anaesthetic injected immediately after the -5 min sample. Control animals received an equivalent volume of saline at this point. A further blood sample was drawn before the glucose injection (time 0), with subsequent blood sampling as with the inhalational anaesthesia experiments. [8].

Blood samples were processed as described previously

\section{Administration of Anaesthesia to Animals}

The inhalational agents (diethyl ether and halothane) were administered by passing a flow of pure oxygen ( $2 \mathrm{~L} / \mathrm{min}$ ) through the precision vaporizer and subsequently into a small exposure chamber into which the animal was placed, the rate of flow being sufficient to prevent any accumulation of $\mathrm{CO}_{2}$.

Sodium pentobarbitone and ketamine hydrochloride were given intravenously ( $30 \mathrm{mg} / \mathrm{kg}$,) as $30 \mathrm{mg} / \mathrm{ml}$ solutions in $0.9 \%$ saline. The animals anaesthetised by the intravenous route, and the control unanaesthetised animals were also exposed to two litres of oxygen per minute in the exposure chamber during the experiments. In addition to providing identical experimental conditions, this procedure prevented the fall in rectal temperature following sodium pentobarbitone which was noted in preliminary experiments.

\section{Isolated Perfused Rat Panereas}

The organ was isolated from fed rats and perfused according to the method of Sussman et al. [9], using an Ambec perfusion unit (Beck Industries Inc. Boulder, Colo., U.S.A.). The perfusate was a mixture of KrebsRinger bicarbonate solution containing 20\% heparinised rat blood and $2.5 \%$ bovine alburain and was gassed with $95 \%$ oxygen and $5 \%$ carbon dioxide. Perfusion flow rate and pressure were kept at $2 \mathrm{ml} / \mathrm{min}$ and $40-60 \mathrm{mmHg}$ respectively. All the venous effluent was collected at timed intervals and assayed for immunoreactive insulin and glucose. Halothane $(2.5 \% \mathrm{v} / \mathrm{v})$ was introduced into the circuit as described in the text.

\section{Calculations}

Glucose and insulin increment values $(\Delta \mathrm{G}$ and $\Delta \mathrm{I})$ were obtained by subtracting the $0 \mathrm{~min}$ value from the values obtained after glucose. Total 30 min glucose and insulin areas were derived from the areas under the glucose and insulin curves. Glucose disappearance rate $(\mathrm{kg})$ was calculated from the absolute blood glucose values between 2.5 and $20 \mathrm{~min}$ [10]. Statistical significance was assessed with the Student " $t$ " test. Results are presented as the mean \pm S.E.M

\section{Results}

\section{Blood Glucose, Plasma Insulin and Glucose Tolerance during Anaesthesia in $48 \mathrm{~h}$ Starved Rats}

a) Ether. A significant rise in fasting blood glucose $(3.7 \pm 0.2$ to $5.2 \pm 0.6 \mathrm{mM} ; p<0.05)$ and plasma insulin $(9 \pm 1$ to $25 \pm 6 \mu \mathrm{U} / \mathrm{ml} ; p<0.05)$ occurred after $30 \mathrm{~min}$ of anaesthesia, compared with unanaesthetised controls (Fig. 1). All blood glucose and glucose increment $(\Delta G)$ values after the glucose injection were significantly increased over control unanaesthetised values, with a decrease in glucose disappearance rate $(1.84 \pm 0.08 \% / \mathrm{min} \quad \nabla . \quad 2.80 \pm 0.28 \% / \mathrm{min} \quad p<0.05)$ (Table 1).
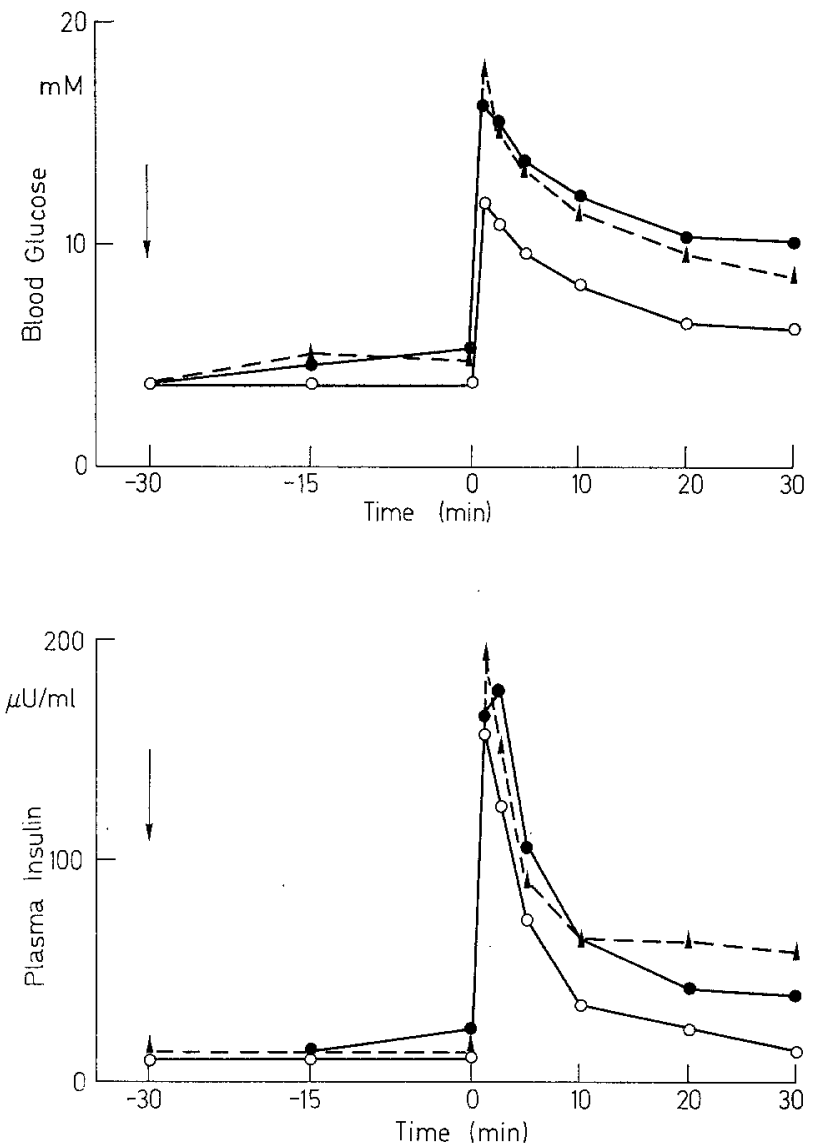

Fig. 1. The effects of ether and halothane anaesthesia on blood glucose and plasma insulin in $48 \mathrm{~h}$ starved rats. Ether $(6.8 \% \mathrm{v} / \mathrm{v})$, shown by $(\mathrm{n}: 5)$, or halothane $(1.5 \% \mathrm{v} / \mathrm{v})$, shown by $\boldsymbol{\Delta}-\boldsymbol{\Lambda}(\mathrm{n}: 5)$ were administered after the $-30 \mathrm{~min}$ sample had been drawn (indicated by $\downarrow)$. Control animals, shown by $\circ-0(n: 6)$, were exposed only to oxygen. Glucose $(0.5 \mathrm{~g} / \mathrm{kg})$ was given intravenously after the 0 min sample had been drawn with subsequent timing from the end of the injection. Each point represents the mean of the values obtained for each group. All blood glucose values for sample times $0-30$ min for the ether and halothane groups are significantly different $(p<0.05)$ from control values. Plasma insulin values for sample times $0-30 \mathrm{~min}$ (ether) and 20 and 30 min (halothane are significantly different $(p<0.05)$ from control values 
The changes in blood glucose were accompanied by significant increases in plasma insulin, particularly in the latter stages of the test with no significant change in insulin to glucose ratio. This suggests hyperglycaemia secondary to decreased peripheral glucose uptake rather than decreased pancreatic responsiveness.

b) Halothane. A significant rise in fasting blood glucose ( 3.9 to $4.9 \mathrm{mM} ; p<0.01$ ) occurred after $30 \mathrm{~min}$ of anaesthesia without a concurrent rise in plasma insulin (Fig. 1). The response to glucose was, however, similar to that seen with the ether anaesthetised animals. Blood glucose values, glucose increment values $(\Delta G)$, ratios between the two groups, although insulin values tended to be higher than in controls. Thus pentobarbitone anaesthesia caused glucose intolerance and hyperglycaemia despite appropriate insulin levels, due possibly to a defect in peripheral glucose assimilation.

d) Ketamine hydrochloride. Ketamine had less effect on glucose and insulin than the three other anaesthetic agents tested in starved rats (Table 1). There was a $15 \%$ increase in total glucose area with ketamine hy. drochloride $(p<0.05)$, although glucose disappearance, plasma insulin and insulin/glucose ratios were within normal limits.

Table 1. Blood glucose, plasma insulin and glucose tolerance during andesthesia in 48 h starved tats

\begin{tabular}{|c|c|c|c|c|c|}
\hline $\begin{array}{l}\text { Time } \\
\min \end{array}$ & $\begin{array}{l}\text { Control } \\
(6)\end{array}$ & $\begin{array}{l}\text { Ether } \\
\text { (5) }\end{array}$ & $\begin{array}{l}\text { Halothane } \\
\text { (5) }\end{array}$ & $\begin{array}{l}\text { Pentobarbi- } \\
\text { tone } \\
(5)\end{array}$ & $\begin{array}{l}\text { Keta- } \\
\text { mine } \\
(4)\end{array}$ \\
\hline \multicolumn{5}{|c|}{ a) $\mathrm{kg}(\% / \mathrm{min})$} & $3.08 \pm 0.31$ \\
\hline \multicolumn{6}{|c|}{ b) Pretest blood glucose (mM) } \\
\hline $\begin{array}{l}\text { c) } \Delta G \\
1 \\
2.5 \\
5 \\
10 \\
20 \\
30\end{array}$ & $\begin{array}{l}8.3 \pm 0.4 \\
7.1 \pm 0.1 \\
5.8 \pm 0.1 \\
4.2 \pm 0.1 \\
2.5 \pm 0.2 \\
2.3 \pm 0.3\end{array}$ & $\begin{array}{r}10.9 \pm 1.6^{\mathrm{b}} \\
10.4 \pm 2.6^{\mathrm{b}} \\
8.6 \pm 2.1^{\mathrm{b}} \\
7.0 \pm 4.2^{\mathrm{b}} \\
5.2 \pm 1.6^{\mathrm{b}} \\
4.9 \pm 2.2^{\mathrm{b}}\end{array}$ & $\begin{array}{r}12.8 \pm 2.2^{\mathrm{b}} \\
10.3 \pm 1.9^{\mathrm{b}} \\
8.6 \pm 1.6^{\mathrm{b}} \\
6.5 \pm 4.2^{\mathrm{b}} \\
4.9 \pm 3.5^{\mathrm{b}} \\
3.9 \pm 0.7^{\mathrm{b}}\end{array}$ & $\begin{array}{l}8.8 \pm 0.2 \\
7.8 \pm 0.5 \\
6.6 \pm 0.4 \\
5.2 \pm 0.5 \\
4.8 \pm 0.4^{\mathrm{a}} \\
2.9 \pm 0.4\end{array}$ & $\begin{array}{r}10.3 \pm 0.9 \\
8.6 \pm 0.8 \\
6.9 \pm 0.5 \\
4.8 \pm 0.2 \\
2.5 \pm 0.2 \\
2.8 \pm 0.2\end{array}$ \\
\hline \multicolumn{6}{|c|}{ d) Pretest plasma insulin $\left(u \mathrm{U}^{-1} \mathbf{l}^{-1}\right)$} \\
\hline $\begin{array}{l}\text { e) } \Delta I \\
1 \\
2.5 \\
5 \\
10 \\
20 \\
30\end{array}$ & $\begin{array}{l}1-1) \\
145 \pm 23 \\
111 \pm 8 \\
59 \pm 12 \\
24 \pm 4 \\
12 \pm 3 \\
8 \pm 2\end{array}$ & $\begin{array}{c}140 \pm 16 \\
151 \pm 20 \\
81 \pm 14 \\
43 \pm 11 \\
24 \pm 7 \\
23 \pm 6^{\mathrm{a}}\end{array}$ & $\begin{array}{c}177 \pm 48 \\
136 \pm 28 \\
77 \pm 20 \\
49 \pm 11 \\
49 \pm 12^{a} \\
42 \pm 7 \mathrm{a}\end{array}$ & $\begin{array}{c}164 \pm 10 \\
121 \pm 12 \\
55 \pm 11 \\
34 \pm 10 \\
27 \pm 6^{3} \\
15 \pm 5\end{array}$ & $\begin{array}{r}158 \pm 23 \\
90 \pm 17 \\
45 \pm 4 \\
20 \pm 4 \\
8 \pm 6 \\
6 \pm 2\end{array}$ \\
\hline \multicolumn{6}{|c|}{ f) Total $30 \mathrm{~min}$ insulin area $\left(\mu \mathrm{U} \mathrm{ml}^{-1} 30 \mathrm{~min}^{-1}\right)$} \\
\hline g) To & $3.8 \pm 4.5$ & $195.9 \pm 11.9^{\mathrm{b}}$ & $185.7 \pm 8.0^{\mathrm{b}}$ & $152.9 \pm 4.1^{\mathrm{b}}$ & $130.9 \pm 5.5^{\mathrm{a}}$ \\
\hline
\end{tabular}

Fig. in parentheses are the numbers of experiments for each group. Results \pm S.E.M. $a=p<0.05, b=p<0.01$ compared with control value. Pretest plasma insulin and blood glucose values refer to the samples drawn immediately before intravenous glucose was given but after anaesthesia was commenced. See text for premanaesthetic values. Glucose was infused at time 0 as described in the text.

and total 30 min glucose area were all significantly increased compared with controls (Table 1). However, glucose disappearance was not affected $(2.36 \pm 0.38 \%$ / min for the halothane group, $2.80 \pm 0.28 \% / \mathrm{min}$ for controls). Plasma insulin was higher throughout but this achieved significance only at 20 and 30 min after glucose.

c) Sodium pentobarbitone. No change in fasting blood glucose or plasma insulin occurred five minutes after induction of anaesthesia. Intravenous glucose tolerance was significantly decreased $(1.67 \pm 0.29 \%$ / min compared with $2.80 \pm 0.28 \% / \min ; p<0.05)$, with a marked rise in total $30 \mathrm{~min}$ glucose area (Table 1 ). There was no significant difference in insulin/glucose

\section{Blood Glucose, Plasma Insulin and Glucose Tolerance datring Anaesthesia in Fed Rats}

Unanaesthetised control fed animals showed improved glucose tolerance, a greater insulin response and higher basal blood glucose and plasma insulin than control $48 \mathrm{~h}$ starved animals.

a) Halothane. In contrast to the starved situation there was a highly significant $(50 \%)$ fall in plasma insulin 30 min after induction of anaesthesia. This was accompanied by a small rise in blood glucose (Fig. 2) and was followed, after the glucose injection, by a blunted insulin response. The insulin values were com. parable to those found in starved animals. Total 30 min insulin area was significantly decreased, $(1492 \mu \mathrm{U}$ 
$\mathrm{ml}^{-1} 30 \mathrm{~min}^{-1}$ compared with $2496 \mu \mathrm{U} \mathrm{ml} \mathrm{ml}^{-1} 30 \mathrm{~min}^{-1}$ for controls; $p<0.05$ ) and total $30 \mathrm{~min}$ glucose area increased. Thus insulin secretion was markedly suppressed in the fed animal, which must have contributed to the subsequent hyperglycaemia.
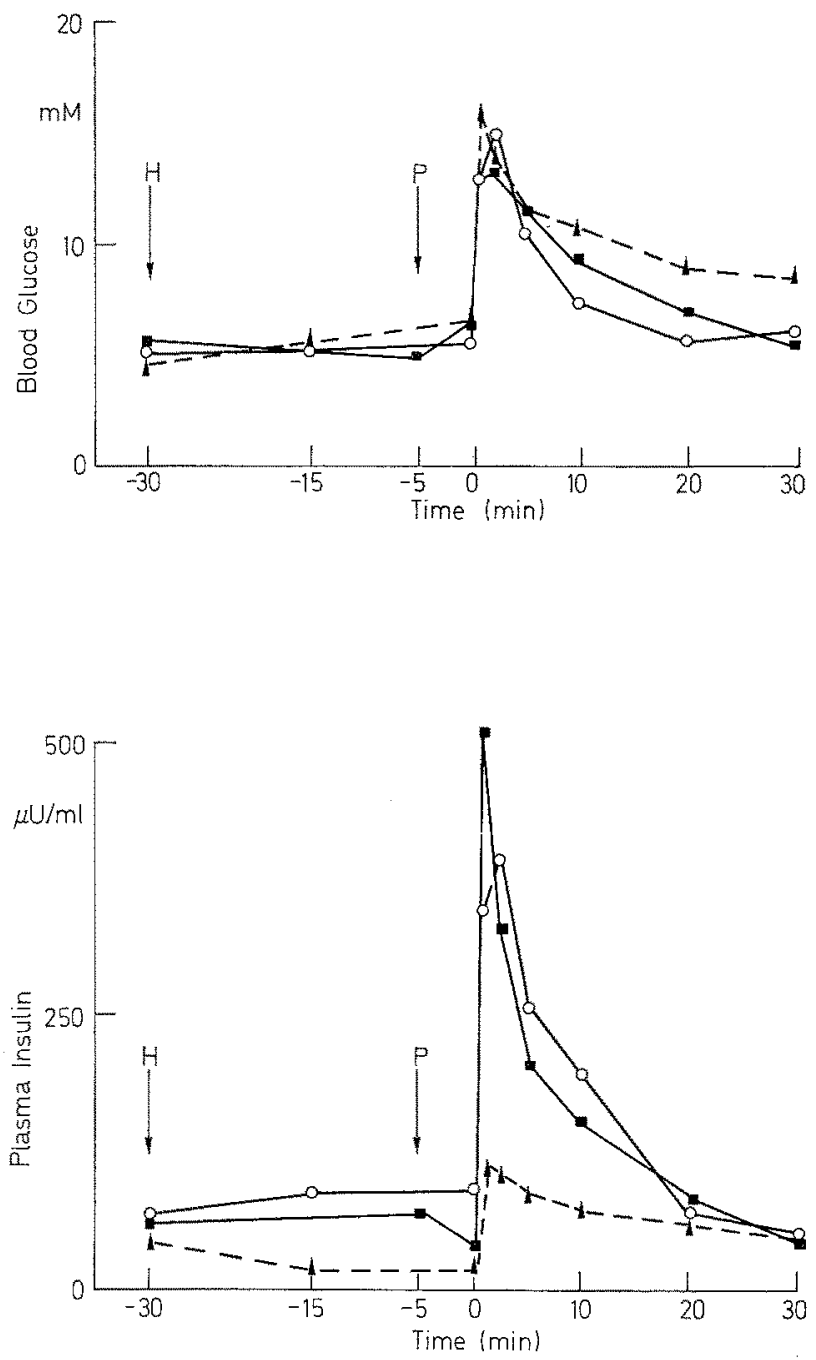

Fig. 2. The effects of pentobarbitone sodium and halothane anaesthesia on blood glucose and plasma insulin in fod rats. Pentobarbitone $(30 \mathrm{mg} / \mathrm{kg})$, shown by $(\mathrm{n}: 5)$ was injected intravenously af ter the $-5 \mathrm{~min}$ sample had been taken (indicated by $\mathrm{P} \downarrow)$. Halothane $(2.5 \% \mathrm{v} / \mathrm{v})$, shown by $A(n: 5)$ was administered after the -30 min sample had been drawn (indicated by $\mathrm{H}_{\downarrow}$ ). Control animals shown by $0-O(n: 5)$ received only oxygen. Glucose $(0.5 \mathrm{~g} / \mathrm{kg})$ was given intravenously after the $0 \mathrm{~min}$ sample had been drawn, with subsequent timing from the end of the injection. Each point represents the mean of the values obtained for each group. The plasma insulin values for times -15 to 10 min for the halothane group and 0 and 1 min for the pentobarbitone group are signifi. cantly different to control values $(p<0.05)$. The blood glucose values for sample times $1-30 \mathrm{~min}$ for the halothane group are significantly different to control values $(p<0.05)$ b) Sodium pentobarbitone. A similar highly significant $(40 \%)$ decrease in basal plasma insulin occurred $5 \mathrm{~min}$ after induction of pentobarbitone anaesthesia, with a small increase in blood glucose (Fig. 2). How. ever, in contrast to halothane, intravenous injection of glucose resulted in an exaggerated peak insulin response, although there were no significant changes in blood glucose, total $30 \mathrm{~min}$ glucose area and total insulin area. Glucose tolerance was unaffected in the fed animals in marked contrast to the glucose intolerance found in the starved state.

\section{The Effect of Halothane on Insulin Secretion by the Isolated Perfused Rat Panereas}

Table 3 shows the effects of halothane on insulin secretion by the isolated perfused rat pancreas. After an initial $100 \mathrm{mg}$ glucose pulse halothane $(2.5 \% \mathrm{v} / \mathrm{v})$ was added to the $\mathrm{O}_{2} / \mathrm{CO}_{2}$ mixture oxygenating the perfusion medium of the test pancreases. The two control pancreases had no halothane added. After a further 20 min control period glucose was added to the medium giving a final concentration of $20 \mathrm{mM}$. Halothane administration was stopped $20 \mathrm{~min}$ later. There were no significant difference between control and test perfusions except after the end of halothane, suggesting an "off-effect". However, the test perfusions had a higher response to the glucose pulse and on a percentage basis the late changes although still present were not significant. In these experiments $3.3 \mathrm{mM}$ glucose was present throughout the early part of the perfusion. In two other perfusions where $3.3 \mathrm{mM}$ glucose was omitted from the initial perfusion medium absolute insulin responses were much smaller. However when halothane was stopped during a subsequent $20 \mathrm{mM}$ glucose infusion there was again an "off-effect". The significance of this is unclear. There was no difference in arterial pressures between halothane and control perfusions.

\section{Diseussion}

Glucose intolerance during anaesthesia has been described in studies in man and experimental animals. In man, ether [11], halothane [12, 13], and pentobarbitone [14] cause intolerance to intravenous glucose. Interpretation of data from most human studies is complicated by the additional influences of drugs ased for premedication, induction and maintenance of anaesthesia. Studies in the rat have shown intolerance to oral [15], subcutaneous [15] and intravenous [16] glucose under barbiturate anaesthesia. However, few studies have correlated changes in glucose metab. olism with changes in plasma insulin response and dietary state, under the influence of different anaesthetic agents. The effects of ketamine hydrochloride on glucose tolerance and plasma insulin have also not been previously reported.

Both ether and halothane caused a rise in fasting blood glucose after thirty minutes of anaesthesia in the 
starved animal. This was accompanied by a rise in plasma insulin only in the ether group. In fed animals, there was a similar rise in basal blood glucose with halothane, but this time there was a highly significant decrease in plasma insulin. Bito and Eakins [17] have also shown this hyperglycaemic effect in rabbits. Different effects in fed and starved animals were also seen five minutes after induction of anaesthesia with pentobarbitone sodium. There was no effect in starved animals but glucose rose and plasma insulin fell in fed animals. Others have reported hyperglycaemia in fed sodium anaesthesia, but were abolished in the fed group.

In contrast, halothane did not cause glucose intolerance in starved animals despite increasing the total glucose area. However, plasma insulin although higher did not rise significantly above control values in the first ten minutes after glucose despite the hyperglycaemia. The decreased plasma insulin response is greatly accentuated in the fed group exposed to halothane where the total insulin area is only $60 \%$ of the control area.

Table 2. Plasma insulin, blood glucose and glucose tolerance during anaesthesia in fed animals

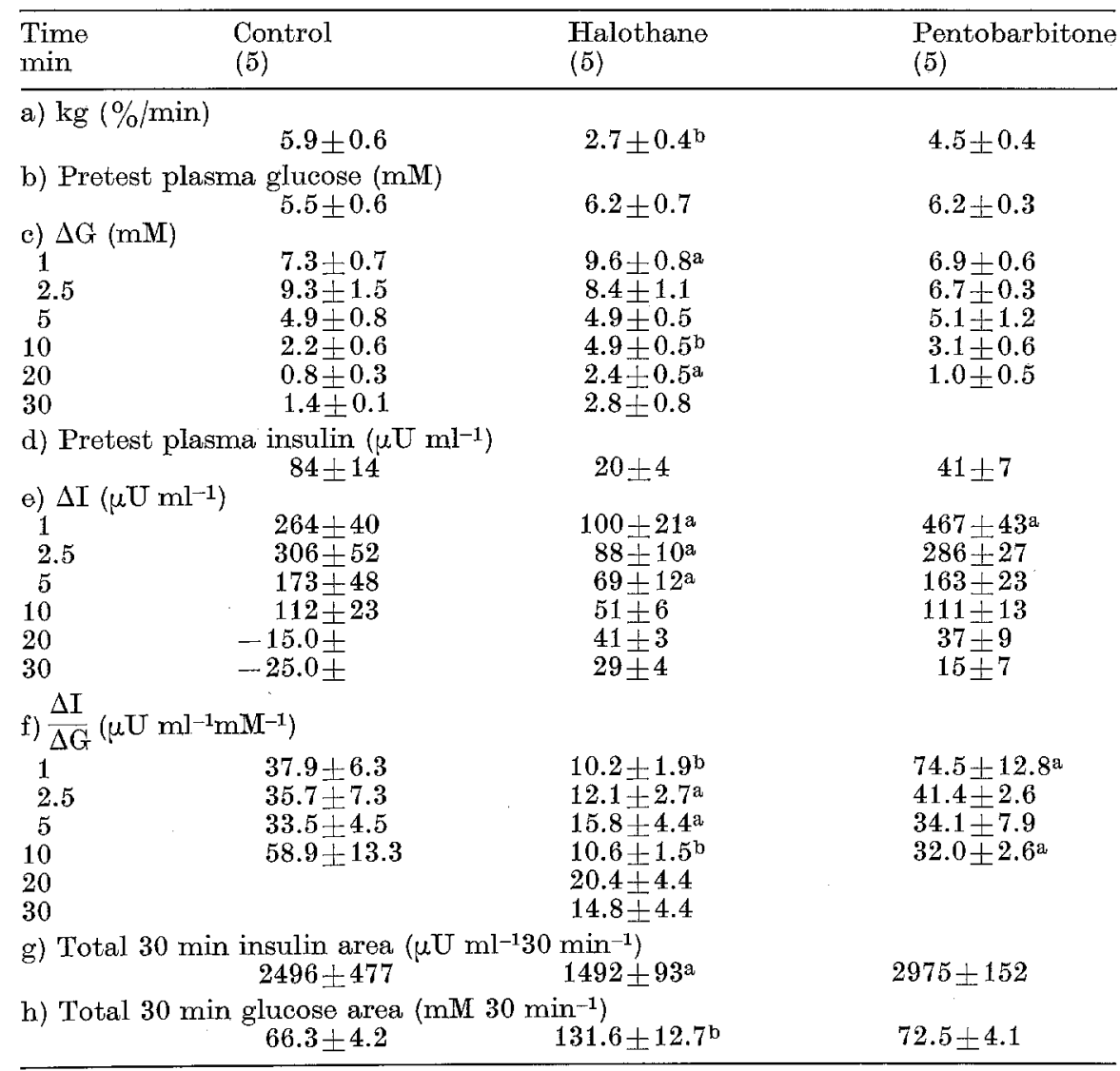

Fig. in parentheses are the numbers of experiments for each group. ${ }^{\mathrm{a}}=p<0.5$, $\mathrm{b}=p<0.01$ compared with control value. Results \pm S.E.M.

[18] but not in $24 \mathrm{~h}$ starved rats with similar doses of pentobarbitone [19]. Ketamine hydrochloride had no effect on fasting blood glucose or plasma insulin. Benke [19] also found no effect of ketamine in $24 \mathrm{~h}$ starved normal rats but interestingly noted a marked rise in glucose in alloxan diabetic rats.

Following the glucose injection ether, in starved animals, caused hyperglycaemia and a marked decrease in glucose disa ppearance rate despite a normal insulin to glucose area ratio. Similar, but less pronounced, effects were seen in the starved group under pentobarbitone
Ketamine hydrochloride had less effect than the other agents in starved animals, causing only a $15 \%$ increase in glucose area. Glucose disappearance rate and total insulin area were not affected, the total insulin area being appropriate for the slight rise in blood glucose.

The manifest effects of anaesthesia in the whole animal are the result of a complex interaction of enzymatic, hormonal, cardiovascular and neurological mechanisms. The effects could be due to at least three mechanisms: changes in endocrine secretion, in the 
hepatic handling of glucose, and in the peripheral uptake of glucose.

The hyperglycaemic effect of ether has been said to be secondary to increased catecholamine release [20]. It is unlikely that the rise in fasting blood glucose seen in the present study with ether and halothane is due to this mechanism since hepatic glycogen stores are almost totally depleted after starvation, and Cori [21] has shown that glycogen stores must be present for this effect. It is more likely that these changes are due to factors affecting glucose utilisation. The fall in plasma in fed animals observed five minutes after administration, although it is not clear why this effect was not seen in starved animals.

Ether, halothane and pentobarbitone sodium all increase the blood levels of other hormones which could in turn affect plasma insulin and blood glucose. Both ether and halothane increase A.C.T.H. and cortisol levels in man [26, 27], whilst pentobarbitone sodium, but not ether, stimulates growth hormone in the rat [28]. The importance of these hormones in the effects reported here is speculative.

Table 3. Effect of halothane on insulin secretion by the isolated perfused rat pancreas

\begin{tabular}{|c|c|c|c|c|}
\hline Time $(\min )$ & $\begin{array}{l}\text { Test (4) } \\
\mu \mathrm{U}_{\text {min }^{-1}}\end{array}$ & $\%$ Response & $\begin{array}{l}\text { Control (2) } \\
\mu \mathrm{U} \text { min }^{-1}\end{array}$ & $\%$ Response \\
\hline 0 Start of perfusion & $221.2 \pm 56.2$ & 427 & 150.0 & 498 \\
\hline$\tilde{5}$ & $87.4 \pm 11.0$ & 173 & 44.8 & 154 \\
\hline 10 & $51.2 \pm 7.4$ & 100 & 29.2 & 100 \\
\hline $15100 \mathrm{mg}$ glucose pulse & $369.6 \pm 55.6$ & 721 & 122.4 & 419 \\
\hline 17 & $230.8 \pm 34.8$ & 469 & 87.6 & 301 \\
\hline 19 & $76.0 \pm 15.8$ & 151 & 28.8 & 99 \\
\hline 24 & $59.4 \pm 7.4$ & 123 & 22.8 & 77 \\
\hline 29 Halothane started & $47.4 \pm 2.4$ & 102 & 22.6 & 77 \\
\hline 34 & $34.4 \pm 3.8$ & 69 & 14.0 & 48 \\
\hline 39 & $30.4 \pm \quad 3.4$ & 61 & 19.4 & 65 \\
\hline 44 & $29.2 \pm 7.2$ & 56 & 11.8 & 41 \\
\hline $\begin{array}{l}49 \text { Glucose infusion } 20 \mathrm{mM} \text {, } \\
\text { started }\end{array}$ & $83.8+14.4$ & 164 & 52.4 & 180 \\
\hline 51 & $69.8 \pm 14.6$ & 140 & 50.0 & 172 \\
\hline 53 & $43.2 \pm 2.8$ & 91 & 37.8 & 130 \\
\hline 55 & $43.4 \pm 5.4$ & 89 & 31.4 & 131 \\
\hline 57 & $46.2 \pm 1.8$ & 97 & 31.4 & 103 \\
\hline 59 & $50.2 \pm 6.8$ & 126 & 31.4 & 107 \\
\hline 64 & $51.0 \pm 2.2$ & 110 & 43.2 & 148 \\
\hline 69 Halothane stopped & $66.2 \pm 17.2$ & 137 & 47.8 & 154 \\
\hline 72 & $84.0 \pm 17.6$ & 174 & 46.2 & 159 \\
\hline 75 & $106.0 \pm 23.0$ & 222 & 48.2 & 155 \\
\hline 78 & $106.4 \pm 20.6$ & 252 & 48.8 & 188 \\
\hline 81 & $121.6 \pm 23.2$ & 286 & 60.0 & 199 \\
\hline 84 & $136.0 \pm 22.2$ & 322 & 52.2 & 190 \\
\hline 87 & $154.6 \pm 23.8$ & 369 & 51.0 & 170 \\
\hline
\end{tabular}

Number of perfusions given in parentheses. Results \pm S.E.M. For $\%$ reponses the baseline sample immediately preceding the glucose pulse was taken as $100 \%$.

insulin in fed animals and the decreased insulin response after glucose in both groups with halothane could be due to increased sympathetic activity since Porte et al. [22] have demonstrated decreased plasma insulin levels after epinephrine infusion. On the other hand Allison et al. [12] have shown that infusion of phentolamine in man did not prevent the decreased insulin response to glucose injected during halothane anaesthesia, and others have disputed whether halothane in fact elicits a sympathetic response [23, 24]. Our results from the perfused pancreas suggest that halothane does not have a direct inhibitory effect on insulin secretion from the pancreas. Other mechanisms of action must be sought.

Pentobarbitone sodium has been shown not to affect insulin secretion in vitro [25] but with this agent, catecholamine induced inhibition of insulin release could be implicated to explain the fall in insulin levels
The influence of anaesthesia on hepatic function could also be involved. Ether [11], halothane [3] and barbiturates [29] all affect hepatic enzymes involved in glucose homeostasis, and further, these enzymes are profoundly influenced by nutritional state [3]. In addition, hepatic blood flow has been shown to be decreased during anaesthesia in man [30, 31] which could affect clearance of glucose. Brunner [32] has demonstrated decreased uptake of glucose by skeletal muscle in vitro in the presence of ether whilst Merin [33] has suggested that halothane interferes with myocardial uptake of glucose. On the other hand, Davidson [16] demonstrated increased uptake of glucose by skeletal muscle in vitro in the presence of pentobarbitone.

In conclusion, the effects of halothane could be due to alterations in tissue blood flow and blood pressure although appropriate measurements were not performed in our study. The effects of ether and pento- 
barbitone sodium are probably due to effects on the hepatic and peripheral handling of glucose, together with changes in regional blood flow. The decrease in basal plasma insulin seen in fed animals anaesthetised with pentobarbitone sodium could be due to increased sympathetic activity, and the use of adrenergic blocking drugs or the direct measurement of plasma catecholamines may help resolve this.

The main implications of this study are that experimental data derived from glucose tolerance tests performed under anaesthesia should be interpreted in the light of the effects of the anaesthetic, and that such effects are dependent on nutritional status.

Similar studies in man may help the selection of the most suitable anaesthetic for patients in whom the metabolic effects of anaesthesia could be important.

Acknowledgements. A. A-G was the recipient of a Wellcome Junior Research Fellowship and the Beaney Scholarship in Materia Medica from Guy's Hospital, London. J.F.B. was the recipient of a Nuffield Research Fellowship from the Nuffield Dominions Trust. K.G.M. M.A. thanks the Wellcome Trust for financial support. The authors thank Miss H. Kuresova and Mrs. Robin Roe for technical assistance, and Professor P.B. Beeson for facilities to carry out this work.

\section{References}

1. Reynoso, A.: Note sur le passage du sucre dans les urines, a propos d'une note du Docteur Harley sur le meme sujet. C. R. Soc. Biol. 5, 116 (1853).

2. Greene, N.M.: Inhalation anaesthetics and carbohydrate metabolism. Baltimore: Williams and Williams Co. 1963.

3. Biebuyck, J.F.: Metabolic effects of halothane with particular reference to the liver. D. Phil. Thesis. University of Oxford 1971.

4. Biebuyck, J.F., Alberti, K.G.M.M.: Influence of altered dietary and endocrine states on the effects of anaesthetic agents on serum insulin and blood metabolites. Submitted for publication (1972).

5. Soeldner, J.S., Slone, D.: Critical variables in the radioimmunoassay of serum insulin using the double antibody technic. Diabetes 14, $771-779$ (1965).

6. Aynsley-Green, A., Alberti, K.G.M.M.: Serum-insulin or plasma-insulin ? Lancet 1972 I, 318-319.

7. Slein, M.W.: D-Glucose. Determination with hexokinase and glucose-6-phosphate dehydrogenase, p. 117. In: Methods of Enzymatic Analysis. (Ed. Bergmeyer, H). Weinheim: Verlag Chemie 1965.

8. Aynsley-Green, A., Alberti, K. G.M.M.: Diuretics and carbohydrate metabolism: The effects of furosemide and amiloride on blood glucose plasma insulin and cations in the rat. Diabetologia 9, 34-42 (1973).

9. Sussman, K.E., Vaughan, G.D., Timmer, R.F.: An in vitro method for studying insulin secretion in the perfused isolated rat pancreas. Metabolism 15, 466476 (1966).

10. Ikkos, D., Luft, R.: On the intravenous glucose tolerance test. Acta endocr. Copenh. 25, 312-334 (1957).

11. Drucker, W.R., Costley, C., Stults, R., Hodlen, W.D., Craig, J., Miller, M., Hoffman, N., Woodward, H.: Studies on carbohydrate metabolism during ether anaesthesia. I Effect of ether on glucose and fructose Metabolism 8, 827-846 (1959).

12. Allison, S.P., Tomlin, P.J., Chamberlain, M.J.: Some effects of anaesthesia and surgery on carbohydrate and fat metabolism. Brit. J. Anaesth. 41, 588-592 (1969).

13. Mérin, R.G., Samuelson, P.N., Schalch, D.S.: Major inhalation anesthetics and carbohydrate metabolism. Anesth. Analg. Curr. Res. 50, 625-632 (1971).

14. Goldsmith, M.W., Holmes, F.: Thiopentone and carbohydrate metabolism. Anesthesia 12,321 - 325 (1957).

15. Stevens, C. D., Herzog, W., Turner, M.Z.: Production of temporary prolonged hyperglyeaemia by the administration of glucose with barbiturates and sulfapyrazine. J. Pharmacol. exp. Ther. 141, 267-273 (1963).

16. Davidson, M.B. : Studies on the Mechanism of Pentobarbital-Induced Glucose Intolerance. Horm. Metab. Res. 3, 243-247 (1971).

17. Bito, L.Z., Eakins, K. E.: The effect of general anaesthesia on the chemical composition of blood plasma of normal rabbits. J. Pharmacol. exp. Ther. 169, 277-286 (1969).

18. Furner, R.L., Neville, E.D., Talarico, K.S., Feller, D.D.: Effect of pentobarbital on plasma glucose and free fatty acids in the rat. Proc. Soc. exp. Biol. 139, $231-234$ (1972).

19. Benke, A.: Der Einfluß einiger i.v.-Narkotica auf Glucosespiegel und Säure-Basenstatus des Blutes alloxandiabetischer Ratten. Der Anaesthesist 20, $348-354$ (1971).

20. Brewster, W.R., jr., Bunker, J.P., Beecher, H.K.: Metabolic effects of anesthesia: VI. Mechanism of metabolic acidosis and hyperglycaemia during ether anesthesia in the dog. Amer. J. Physiol. 171, 37-47 (1952).

21. Cori, C.F.: Mammalian carbohydrate metabolism. Physiol. Rev. II, 143-275 (1931).

22. Porte, D. jr., Graber, A.L., Kuzuya, T., Williams, R. H.: The effect of epinephrine on immunoreactive insulin levels in man. J. clin. Invest. 45, 228-236 (1966).

23. Price, H. L., Linde, H.W., Jones, R.E., Black, G.W., Price, M. L.: Sympatheto-adrenal responses to general anesthesia in man and their relation to hemodynamics. Anesthesiology 18, 563-575 (1959).

24. Price, H.L., Skovsted, P., Pauca, A.L., Cooperman, L.H.: Evidence for beta-receptor activation produced by halothane in normal man. Anesthesiology 32, $389-$ 395 (1970).

25.. Kizer, J.S., Vargas-Cordon, M., Brendel, K., Bressler, R.: The in vitro inhibition of insulin secretion by diphenylhydantoin. J. clin. Invest. 49, 228-236 (1966).

26. Oyama, T., Saito, T., Isomatsu, T., Samejima, N., Uemura, T., Arimura, A.: Plasma levels of A.C.T.H. and cortisol in man during diethyl ether anesthesia and surgery. Anesthesiology 29, 559-564 (1968).

27. Oyama, T., Takiguchi, M.: Plasma levels of A.C.T.H. and cortisol in man during halothane anesthesia and surgery. Anesth. Analg. Curr. Res. 49, 363-366 (1970).

28. Howard, N., Martin, J.M.: A stimulatory test for growth hormone release in the rat. Endocrinology 88, $497-499$ (1971).

29. Brunner, E. A., Haugaard. N. : The effect of thiopental on hepatic glycogen phosphorylase. J. Pharmacol. exp. Ther. 150, 99-104 (1965).

30. Habif, D.V., Papper, E.M., Fitzpatrick, H.F., Lowrance, P., McSmithe, C., Bradley, S.E. : The renal and hepatic blood flow, glomerular filtration rate, and 
urinary output of electrolytes during cyclopropane, ether, and thiopental anesthesia, operation and the immediate post-operative period. Surgery 30, 241255 (1950).

31. Shackman, R., Graber, I.G., Melrose, D.G.: Liver blood flow and general anaesthesia. Clin. Sci. 12, $307-315$ (1953).

32. Brunner, E.A.: The effects of diethyl ether on carbohydrate metabolism in skeletal muscle. Anesthesio$\log y 30,24-28(1969)$.
33. Merin, R.G.: The relationship between inyocardial function and glucose metabolism in the halothane depressed heart. I. The effect of hyperglycemia. Anesthesiology 33, 391-395 (1970).

K. G.M. M. Alberti, D. Phil.

Nuffield Department of Clinical

Medicine

The Radcliffe Infirmary

Oxford

England 